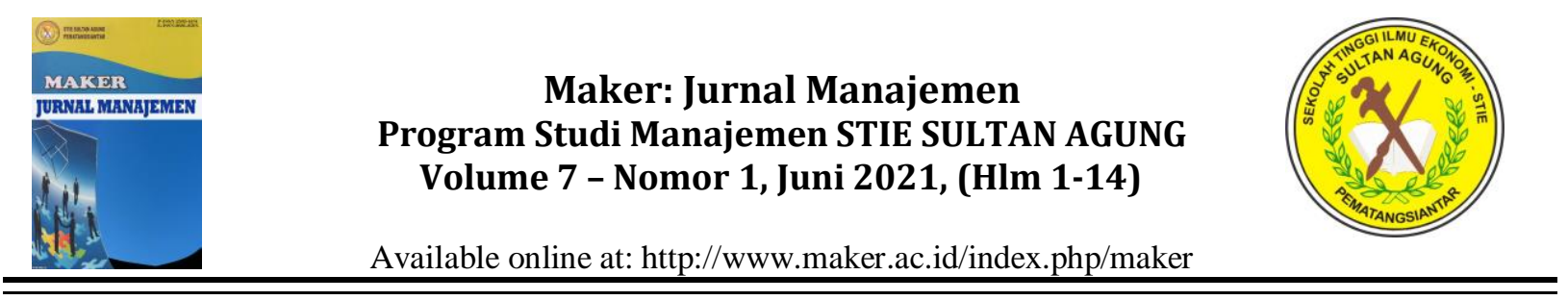

\title{
ANALISIS MOTIVASI KONSUMEN DALAM MELAKUKAN PEMBELIAN DI DEILICIOUS KITCHEN SEBAGAI UPAYA PERBAIKAN STRATEGI PRODUK DAN HARGA
}

\author{
Erika Larasati Fajrina ${ }^{1)}{ }^{*}$, Cecep Safa'atul Barkah ${ }^{2)}$, Arianis Chan ${ }^{3)}$, Pratami Wulan Tresna ${ }^{4)}$ \\ ${ }^{1,2,3,4}$ Program Studi Ilmu Administrasi Bisnis, Universitas Padjadjaran. Jalan Raya Bandung \\ Sumedang Km. 21, Hegarmanah, Kecamatan Jatinangor, Kabupaten Sumedang, Jawa Barat, 45363, \\ Indonesia. \\ E-mail: 1'erika18003@mail.unpad.ac.id, ${ }^{2}$ cecep.barkah@unpad.ac.id, ${ }^{3}$ arianis.chan@unpad.ac.id, \\ pratami@unpad.ac.id
}

\begin{abstract}
Abstrak
Tujuan yang ingin dicapai dari penelitian ini adalah untuk mengetahui motivasi konsumen dalam melakukan pembelian makanan di Deilicious Kitchen. Motivasi konsumen dalam penelitian ini akan dikelompokkan berdasarkan motif pembelian konsumen, yaitu motif pembelian rasional dan motif pembelian emosional. Hasil dari penelitian ini akan dijadikan dasar untuk memperbaiki strategi produk dan harga di Deilicious Kitchen agar dapat berkembang dan bertahan di tengah-tengah persaingan. Penelitian ini menggunakan metode penelitian kuantitatif dengan teknik analisis deskriptif. Metode pengambilan sampel yang digunakan adalah simple random sampling. Sampel dalam penelitian ini adalah 88 konsumen Deilicious Kitchen. Hasil penelitian menunjukkan bahwa terdapat empat motif pembelian yang paling dominan dalam mendorong atau merangsang konsumen untuk melakukan pembelian makanan di Deilicious Kitchen, yaitu: variasi menu dengan nilai rata-rata 4,43; kualitas produk dengan nilai rata-rata 4,38; harga dengan nilai rata-rata 4,07; dan penampilan produk dengan nilai rata-rata 3,78. Empat motif yang paling dominan ini kemudian disarankan untuk menjadi prioritas dari bisnis Deilicious Kitchen dalam perbaikan strategi produk dan harga.
\end{abstract}

Kata kunci: motivasi konsumen, motif rasional, motif emosional

\begin{abstract}
The objectives to be achieved from this research are to determine the motivation of consumers in purchasing food at Deilicious Kitchen. Consumer motivation in this study will be grouped based on consumer purchasing motives, namely rational buying motives, and emotional buying motives. The results of this research will be used as a basis for improving product and price strategies at Deilicious Kitchen so that they can develop and survive in the midst of competition. This research uses quantitative methods with descriptive analysis techniques. Sampling method uses Simple Random Sampling. Sample in this research is 88 people of Deilicious Kitchen Customer. The results showed that there were four dominant buying motives in encouraging or stimulating consumers to purchase food at Deilicious Kitchen, namely: menu variations with an average value 4.43; product quality with an average value 4.38; prices with an average value 4.07; and product appearance with an average value 3.78. The four most dominant motives are then suggested to be the priority of the Deilicious Kitchen business in improving product and price strategies.
\end{abstract}

Keywords: consumer motivation, rational motives, emosional motives

Article History: Received 13 Jan $2021 \quad$ Accepted 26 May $2021 \quad$ Published 30 Jun 2021 


\section{PENDAHULUAN}

Keberadaan teknologi yang canggih menjadi salah satu pendukung kegiatan masyarakat ketika terjadinya pandemi ini. Pandemi Covid-19 membuat pola perilaku masyarakat berubah untuk menyesuaikan dengan keadaan. Salah satu perubahan yang paling terlihat adalah meningkatnya kegiatan belanja online. Berdasarkan hasil survei terkait Demografi Dampak Covid-19 yang dilakukan oleh Badan Pusat Statistik (BPS), diketahui bahwa aktivitas belanja online meningkat sangat tajam. Banyak masyarakat yang melakukan transaksi dari rumah dengan alasan keamanan. Jika diuraikan berdasarkan masing-masing kebutuhan, sebesar 51 persen masyarakat melakukan kegiatan belanja secara online untuk memenuhi kebutuhan makanan, sebanyak 20 persen memenuhi untuk kebutuhan kesehatan, 14 persen untuk membeli pulsa atau paket data, dan sisanya untuk makanan dan minuman jadi serta belanja listrik (Kompas.com, 2020). Perubahan ini dimanfaatkan oleh banyak pembisnis untuk terjun ke bisnis online, termasuk Deilicious Kitchen.

Deilicious Kitchen merupakan sebuah bisnis rumahan yang bergerak di bidang kuliner. Bisnis ini menyediakan berbagai jenis makanan, baik makanan ringan atau lauk-pauk. Bisnis ini didirikan pada Agustus 2020. Pada awalnya, makanan yang ditawarkan oleh Deilicious Kitchen hanya Macaroni Schotel. Tetapi karena ada masukan dari beberapa orang, Deilicious Kitchen akhirnya memutuskan untuk menambah variasi menunya. Beberapa menu baru dari Deilicious Kitchen adalah nasi bakar, brownies, bitterballen, nasi kotak, dan juga lauk makanan sehari-hari. Sebagai sebuah bisnis berbasis online yang baru dibuka pada saat pandemi, Deilicious
Kitchen bisa dikategorikan mendapatkan respon yang positif dari pasar. Berawal dari 10 pesanan pada saat pertama kali membuka pre-order, kini Deilicious Kitchen bisa melayani kurang lebih 60 pesanan setiap bulannya. Makanan yang dipesan pun bervariasi dan ada juga beberapa konsumen yang melakukan pembelian berulang. Angka ini tentunya mencapai target bulanan yang direncanakan oleh Deilicious Kitchen dan membuat keuntungan yang didapat juga semakin besar. Grafik penjualan Deilicious Kitchen dapat dilihat pada Gambar 1 berikut.

\section{Grafik Penjualan Deilicious Kitchen}

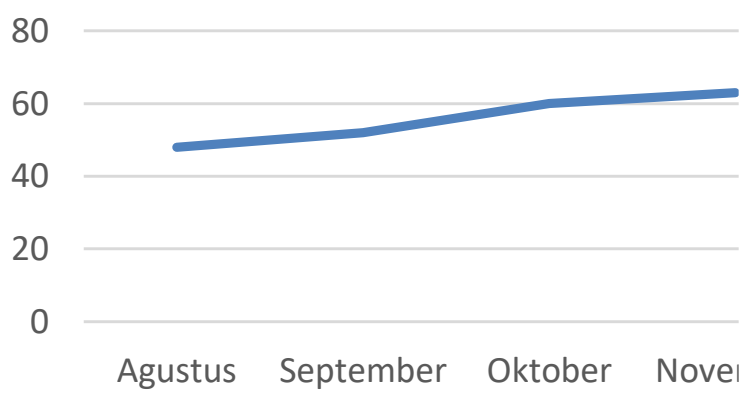

Gambar 1. Grafik Penjualan Deilicious Kitchen

Dalam mengelompokkan konsumennya, Deilicious Kitchen menggunakan pengelompokkan segmentasi demografis dan geografis. Deilicious Kitchen menetapkan target konsumennya adalah remaja hingga dewasa berkisar umur 18 hingga 60 tahun. Lalu untuk wilayah yang dijangkau oleh bisnis ini adalah Provinsi DKI Jakarta dan sekitarnya. Untuk positioning, Deilicious Kitchen berusaha menciptakan citra "makanan rumahan kualitas terbaik dengan harga terjangkau" di benak masyarakat.

Sebagai salah satu bisnis yang masih cukup baru, Deilicious Kitchen masih membutuhkan banyak pengembangan agar dapat bertahan di tengah-tengah persaingan. 
Apalagi saat ini banyak bisnis yang juga menawarkan makanan rumahan dengan kualitas dan kebersihan yang terjamin. Analisis sikap konsumen perlu dilakukan untuk mendukung perkembangan strategi pemasaran dari suatu bisnis. Deilicious Kitchen perlu memahami sikap konsumen yang dilayani agar dapat mencapai kepuasan bagi kedua belah pihak. Bagaimana sikap konsumen dalam membuat keputusan pembelian akan dipengaruhi oleh beberapa faktor, salah satunya adalah faktor psikologis, yaitu motivasi (Setiawan \& Harahab, 2013).

Berdasarkan yang telah diuraikan, maka penelitian ini dilakukan untuk menganalisis motivasi konsumen dalam melakukan pembelian makanan di Deilicious Kitchen. Tujuan yang hendak dicapai dalam penulisan penelitian ini adalah untuk mengetahui variabel motivasi konsumen yang dominan dalam menentukan keputusan pembelian khususnya di Deilicious Kitchen. Hasil yang ditemukan dalam penelitian ini nantinya akan dijadikan dasar untuk memperbaiki strategi produk dan harga sesuai dengan peluang yang ada guna mengembangkan bisnis agar dapat meningkatkan kepuasan pelanggan. Strategi yang disusun juga diharapkan dapat membantu Deilicious Kitchen bertahan di tengah-tengah persaingan.

\section{LANDASAN TEORI \\ Perilaku konsumen}

Berdasarkan Schiffman dan Kanuk yang diadaptasi dalam penelitian (Naashir et al., 2016) mengatakan bahwa perilaku konsumen adalah sebuah perilaku yang ditunjukkan oleh konsumen dalam menggali, membeli, memanfaatkan, melakukan penilaian, dan menghabiskan konsumsi produk serta jasa yang diharapkan dapat memenuhi kebutuhan mereka dan mencapai kepuasan.

Perilaku konsumen adalah kegiatankegiatan individu yang secara langsung terlibat dalam memperoleh dan mempergunakan sebuah barang dan jasa termasuk didalamnya proses pengambilan keputusan pada persiapan dan menentukan kegiatan-kegiatan tersebut (Kotler, 2002). Berdasarkan pengertian yang dipaparkan, maka dapat dilihat bagaimana pentingnya perusahaan atau bisnis untuk memahami perilaku konsumennya. Pemahaman ini dilakukan agar bisnis dapat membuat strategi yang tepat untuk memasarkan produk maupun jasanya. Kemudian perilaku pembelian konsumen dipengaruhi oleh beberapa faktor, yaitu faktor kebudayaan, faktor kelas sosial, faktor personal atau faktor pribadi, dan faktor psikologi (Kotler \& Amstrong, 2001). Salah satu faktor psikologi yang dapat mempengaruhi perilaku pembelian konsumen adalah motivasi.

\section{Motivasi Konsumen}

"Motivation is the driving force that can drive someone to take an action. This represents the person's reasons for acting or behaving in a certain way" (Schiffman \& Wisenblit, 2015), yang dapat diartikan bahwa motivasi merupakan sebuah penggerak yang ada di dalam diri seseorang yang memaksanya atau mendorongnya untuk melakukan sebuah tindakan. Sementara menurut (Setiadi, 2003), motivasi konsumen adalah kesanggupan seseorang untuk mengeluarkan tingkat usaha yang tinggi kearah tujuan yang ingin dicapainya, yang dikondisikan dengan kemampuan usaha untuk memenuhi kebutuhan dari individu. "A motive is a reason why someone does something. The terms need and motivation are used consecutively. The 
reason is when consumer feels the gap between what they want and his or her actual condition, a need will be recognized and experienced as a drive state reffered as motivation" (Mothersbaugh \& Hawkins, 2016), yang artinya bahwa ketika seseorang merasakan ada kesenjangan antara keinginan dengan keadaan, maka akan timbul kebutuhan yang menjadi penggerak dan disebut motivasi.

Seperti yang telah dijelaskan sebelumnya, motivasi menjadi salah satu faktor penggerak atau pendorong konsumen untuk melakukan pembelian. Adapun (Setiadi, 2010) menjelaskan tujuan dari motivasi konsumen adalah meningkatkan kepuasan konsumen, menjaga loyalitas, efisiensi, efektivitas, dan mewujudkan sebuah hubungan yang harmonis antara produsen dan penjual serta pembeli atau konsumen.

"A careful study of buyer behavior reveals that people make buying decision based on both emotional and rational buying motives" (Manning et al., 2012). Dari penjelasan tersebut, maka dapat ditarik kesimpulan bahwa motivasi konsumen untuk melakukan pembelian dibagi berdasarkan faktor atau motif yang mendorongnya, yaitu motif pembelian rasional dan motif pembelian emosional.

\section{Motif Rasional}

"A purchases based on a rational purchase motives is generally the result of an objective review of available information. Buyers will closely examine product or service information in a relatively emotion-free manner" (Manning et al., 2012). Dari pernyataan tersebut, maka dapat dikatakan bahwa motif pembelian rasional merupakan sebuah tindakan pembelian yang didasarkan atas rasionalitas atau merupakan hasil tinjauan objektif dari informasi produk atau jasa yang tersedia. Pembeli akan melakukan observasi atau pembelajaran mendalam tanpa adanya pengaruh emosi di dalamnya. Hasil dari observasi ini nantinya akan dijadikan bahan pertimbangan dalam pengambilan keputusan pembelian.

Menurut Schiffman dan Kanuk dalam (Yusa, 2015), motif rasional terbentuk karena konsumen memilih berlandaskan pada kriteria objektif seperti ukuran, bobot, dan juga harga. Contoh dari pertimbangan pembelian yang didasarkan atas motif rasional adalah pengiriman tepat waktu, keuntungan finansial, kehandalan, efisiensi waktu, peningkatan keuntungan, atau daya tahan produk.

\section{Motif Emosional}

"Recent research has shown that buying much more emotional than most marketers thought. Many Buyers are driven more by feelings than by logic" (Manning et al., 2012). Sementara itu, menurut Setiadi yang diadaptasi dalam (Yusa, 2015), motif emosional adalah motif yang sensitif dengan perasaan sehingga konsumen akan terkesan tergesa-gesa untuk melakukan pembelian produk atau jasa tanpa memikirkan kembali kemungkinan yang akan terjadi untuk jangka waktu yang lebih panjang.

Dari pernyataan diatas, maka dapat dilihat bahwa emosional dari masing-masing konsumen mempunyai peran dalam mendorong konsumen melakukan pembelian. Saat ini banyak konsumen yang lebih terdorong melakukan pembelian karena emosionalnya, bukan didasari oleh pikiran-pikiran yang logis. Motif emosional bisa didasarkan atas rasa senang, rasa bangga, rasa percaya diri, popularitas, rasa aman, rasa takut, dan masih banyak lagi. 


\section{Marketing Mix}

Marketing mix (bauran pemasaran) adalah seperangkat alat pemasaran yang sering disebut sebagai sebuah produk total (total product) yang disajikan kepada target pasar dari suatu bisnis yang akan mempengaruhi pengambilan keputusan seseorang (Mothersbaugh \& Hawkins, 2016). Adapun (Schiffman \& Wisenblit, 2015) menjelaskan bahwa marketing mix mencakup empat elemen, yaitu:

\section{a. Product or service}

Bagian utama dari sebuah bisnis adalah produk dan juga layanan yang ditawarkan. Produk bisa terdiri dari fitur yang ditawarkan, desain produk, kualitas, label produk, kemasan produk, ukuran, ragam produk, dan juga garansi yang diberikan.

b. Price

Harga adalah besar uang yang harus dibayar oleh seseorang untuk mendapatkan hak atas penggunaan produk. Hal ini menyebabkan harga menjadi salah satu hal yang sensitif dalam dunia bisnis. Banyak konsumen yang menjadikan harga sebagai alat pembanding dengan kompetitor. Bagaimana harga yang ditetapkan akan sangat berpengaruh terhadap tingkat penjualan. Harga yang ditawarkan sebaiknya masuk akal dan sesuai dengan kondisi pasar. Harga juga dapat digunakan untuk melambangkan bagaimana kualitas dan citra dari sebuah produk. Harga terdiri atas daftar harga, diskon, promo, dan jangka pembayaran.

c. Place

Tempat dan lokasi sebuah bisnis harus pas dan sesuai karena tempat menjadi salah satu kunci kesukesan bisnis. Sebuah bisnis lebih baik berada di tempat yang strategis agar calon konsumen akan lebih mudah untuk menemukan atau mencari barang yang ditawarkan. Tempat yang strategis juga akan memudahkan dalam proses distribusi produk mulai dari penyimpanan hingga sampai ke tangan konsumen.

d. Promotion

Promosi merupakan strategi yang digunakan oleh pemasar untuk membuat masyarakat atau calon konsumen sadar dengan keberadaan dari produk yang mereka tawarkan. Promosi merupakan bentuk komunikasi bisnis kepada konsumen tentang produk atau layanan yang ada sehingga bisa lebih dikenal. Promosi ini terdiri dari iklan, tenaga penjualan (sales), public relation, dan melalui penjualan langsung.

Berdasarkan penjelasan tersebut, maka marketing mix dapat dikatakan sebagai 'senjata' yang digunakan oleh suatu usaha untuk memasarkan produknya.

\section{Hubungan Motivasi Konsumen dengan Penyusunan Strategi Produk dan Harga}

Seperti yang telah dibahas sebelumnya, "every buying decision has a motive behind it" (Manning et al., 2012). Maka beberapa keputusan pembelian konsumen bisa dipengaruhi oleh beberapa motif pembelian. Motif pembelian kemudian akan menjadi pendorong untuk timbulnya motivasi konsumen. Pebisnis atau pemasar tidak bisa menganggap semua perilaku serta pilihan konsumen untuk melakukan pembelian adalah sama karena masing-masing konsumen memiliki tujuan yang berbeda. Maka dari itu, penting bagi sebuah bisnis untuk mengetahui atau mempelajari hal-hal yang mendorong atau merangsang konsumen untuk melakukan 
pembelian. Sebuah bisnis harus berusaha mengetahui Dominant Buying Motives (DBM) yang mungkin memiliki pengaruh terbesar ketika konsumen melakukan pembelian. Pembelajaran mengenai konsumen ini dilakukan agar sebuah bisnis dapat menentukan atau menyusun strategi pemasaran yang tepat untuk target konsumennya.

"A marketing strategy is formulated in from of the marketing mix. This concerns determining the product features, price, communication, distribution, and service that will provide superior value" (Mothersbaugh \& Hawkins, 2016), yang artinya bahwa strategi pemasaran yang dibuat oleh sebuah perusahaan perlu merumuskan bauran pemasaran dengan baik agar dapat memberikan nilai yang maksimal atau mencapai kepuasan konsumen. Dalam penelitian ini, bauran pemasaran yang akan dirumuskan adalah produk dan harga.

\section{Penelitian Terdahulu}

Penelitian yang dilakukan oleh Setiawan dan Harahab (2013) dalam jurnal yang berjudul "Analisis Motivasi dan Kepuasan Konsumen Terhadap Produk Olahan Seafood" mengungkapkan motivasi konsumen untuk mengkonsumsi produk olahan di restoran seafood Batavia Malang mayoritas dipengaruhi oleh motif rasional dengan pernyataan yang paling dominan, yaitu rasa produk yang enak dan lezat. Untuk motif emosional, pernyataan rasa bangga dalam mengkonsumsi produk menjadi pernyataan yang dominan.

Penelitian yang dilakukan oleh Yusa (2015) dalam jurnal berjudul "Pengaruh Motif Rasional dan Motif Emosional Terhadap Keputusan Pembelian Ponsel Blackberry di Bandar Lampung" mengungkapkan bahwa pengaruh motif emosional lebih besar daripada motif rasional terhadap keputusan pembelian ponsel blackberry. Kriteria motif emosional yang paling dominan adalah rasa senang karena konsumen menggunakan ponsel blackberry untuk berkomunikasi.

\section{METODE}

Berdasarkan permasalahan yang akan diteliti, metode kuantitatif dengan teknik analisis deskriptif digunakan dalam penelitian ini. Menurut (Priyono, 2008), penelitian kuantitatif adalah sebuah penelitian yang menggunakan asumsi dengan pendekatan positivis. Tujuan penelitian kuantitatif dibatasi untuk mendeskripsikan karakteristik apa adanya. Kemudian hasil tersebut akan dijabarkan secara deskriptif.

Analisis deskriptif adalah sebuah teknik penelitian yang mendeskripsikan dan juga menginterpretasi objek apa adanya. Hasil penelitian akan mendeskripsikan data yang diperoleh dan menjawab rumusan masalah penelitian. Metode penelitian kuantitatif deskriptif digunakan untuk mengamati faktor-faktor pendorong atau perangsang konsumen dalam melakukan pembelian.

Adapun objek penelitian dalam penelitian ini adalah motif pembelian rasional (kualitas produk, ukuran, variasi menu, dan harga) serta motif pembelian emosional (penampilan dan rasa senang). Kemudian populasi dari penelitian ini adalah konsumen dari Deilicious Kitchen pada bulan Agustus 2020 hingga November 2020 yang berjumlah 109 orang.

(Sugiyono, 2013) menjelaskan bahwa sampel merupakan bagian dari populasi yang memiliki karakteristik sesuai. Untuk menentukan jumlah sampel yang akan diambil dari populasi, peneliti menggunakan rumus slovin dengan tingkat kepercayaan $95 \%$ dengan nilai $\mathrm{e}=5 \%$ 


$$
n=\frac{N}{1+N e^{2}}
$$

Keterangan:

$n=$ jumlah sampel

$N=$ jumlah Populasi

$e=$ margin of error $(\mathrm{e}=0,05)$

Dari rumus tersebut, maka dapat diketahui bahwa banyak sampel yang akan digunakan dalam penelitian ini adalah minimal sebanyak 86 orang. Lalu, teknik pengambilan sampel yang digunakan dalam penelitian ini adalah pendekatan probability sampling, yaitu simple random sampling. Teknik simple random sampling adalah teknik pengambilan sampel dari anggota populasi yang dilakukan secara random tanpa memperhatikan tingkatan yang ada dalam populasi tersebut atau populasi dianggap homogen (Sugiyono, 2013). Semua sampel diambil dari konsumen Deilicious Kitchen.

\section{HASIL DAN PEMBAHASAN}

\section{Uji Validitas}

Uji Validitas dilakukan menggunakan software SPSS 25 dengan tujuan untuk mengetahui validitas dari setiap item pernyataan yang terdapat di kuesioner. Dengan jumlah sampel (N) sebanyak 88 orang dan tingkat signifikasi 5\%, maka ditemukan bahwa $r_{\text {tabel }}=0,2072$. Hasil uji validitas adalah sebagai berikut:

Tabel 1. Hasil Uji Validitas

\begin{tabular}{|l|c|c|c|}
\hline \multicolumn{1}{|c|}{ Variabel } & Rhitung $_{\text {R }}$ & R$_{\text {tabel }}$ & Keterangan \\
\hline Kualitas (Q1) & 0,391 & 0,2072 & Valid \\
\hline Kualitas (Q2) & 0,218 & 0,2072 & Valid \\
\hline Ukuran & 0,630 & 0,2072 & Valid \\
\hline Variasi Menu & 0,364 & 0,2072 & Valid \\
\hline Harga & 0,440 & 0,2072 & Valid \\
\hline Penampilan (Q1) & 0,428 & 0,2072 & Valid \\
\hline Penampilan (Q2) & 0,503 & 0,2072 & Valid \\
\hline Rasa Senang & 0,513 & 0,2072 & Valid \\
\hline
\end{tabular}

Sumber: data diolah (2020)
Berdasarkan hasil dari perhitungan uji validitas tersebut, ditampilkan bahwa semua item pernyataan dinyatakan valid. Hal tersebut bisa dilihat dari nilai $r_{\text {hitung }}$ yang lebih besar daripada nilai $r_{\text {tabel }}$. Artinya seluruh item pernyataan pada instrumen penelitian (kuesioner) dapat dinyatakan layak digunakan sebagai pengukur data penelitian.

\section{Uji Reliabilitas}

Uji reliabilitas dilakukan menggunakan software SPSS 25 dengan tujuan untuk mengetahui konsistensi dari setiap item pernyataan pada kuesioner. Hasil uji reliabilitas adalah sebagai berikut:

Tabel 2. Hasil Uji Reliabilitas

\begin{tabular}{|l|c|c|c|}
\hline \multicolumn{1}{|c|}{ Variabel } & $\begin{array}{c}\text { Koefisien } \\
\text { Cronbach } \\
\text { Alpha }\end{array}$ & $\begin{array}{c}\text { Nilai } \\
\text { Kritis }\end{array}$ & Keterangan \\
\hline $\begin{array}{l}\text { Kualitas } \\
\text { (Q1) }\end{array}$ & 0,389 & 0,2072 & Reliabel \\
\hline $\begin{array}{l}\text { Kualitas } \\
\text { (Q2) }\end{array}$ & 0,462 & 0,2072 & Reliabel \\
\hline Ukuran & 0,298 & 0,2072 & Reliabel \\
\hline $\begin{array}{l}\text { Variasi } \\
\text { Menu }\end{array}$ & 0,399 & 0,2072 & Reliabel \\
\hline Harga & 0,408 & 0,2072 & Reliabel \\
\hline $\begin{array}{l}\text { Penampilan } \\
\text { (Q1) }\end{array}$ & 0,372 & 0,2072 & Reliabel \\
\hline $\begin{array}{l}\text { Penampilan } \\
\text { (Q2) }\end{array}$ & 0,345 & 0,2072 & Reliabel \\
\hline $\begin{array}{l}\text { Rasa } \\
\text { Senang }\end{array}$ & 0,374 & 0,2072 & Reliabel \\
\hline
\end{tabular}

Sumber: data diolah (2020)

Berdasarkan tabel di atas, dapat dilihat bahwa nilai koefisien Cronbach Alpha dari semua variabel lebih tinggi daripada nilai kritisnya. Maka dapat ditarik kesimpulan bahwa seluruh instrumen variabel reliabel.

\section{Analisis Deskriptif}

Pada bagian ini akan dijelaskan deskripsi terkait variabel motivasi konsumen dalam melakukan pembelian makanan di Deilicious Kitchen. Penyajian akan dilakukan per-variabel dan dijelaskan 
berdasarkan rata-rata dari setiap variabel. Nilai tertinggi dari item pernyataan adalah 5 dan nilai terendahnya adalah 1 . Dari uraian skor tersebut, maka dibuat interval dengan sebagai berikut:

$$
\frac{\text { Skor Tertinggi }- \text { Skor Terendah }}{\text { Jumlah Kelas }}=\frac{5-1}{5}=0,8
$$

Sehingga dapat ditentukan range jawaban sebagai berikut: skor rata-rata 1,00 - 1,80 = Sangat Tidak Setuju; skor rata-rata $1,81-2,60=$ Tidak Setuju; skor rata-rata 2,61 $-3,40=$ Cukup Setuju; skor rata-rata $3,41-4,20=$ Setuju; skor rata-rata 4,21 $5,00=$ Sangat Setuju. Berdasarkan kriteria jawaban tersebut, maka dapat diuraikan secara deskriptif penilaian responden terhadap masing-masing variabel penelitian sebagai berikut.

\section{Analisis Deskriptif Terhadap Kualitas}

Tabel 3. Penilaian Kualitas

\begin{tabular}{|c|l|c|c|}
\hline No & Item Pernyataan & Mean & Kriteria \\
\hline 1 & $\begin{array}{l}\text { Saya membeli } \\
\text { makanan di } \\
\text { Deilicious Kitchen } \\
\text { karena bahan } \\
\text { makanannya yang } \\
\text { bersih dan segar }\end{array}$ & 4,35 & $\begin{array}{l}\text { Sangat } \\
\text { Setuju }\end{array}$ \\
\hline 2. & $\begin{array}{l}\text { Saya membeli } \\
\text { makanan di } \\
\text { Deilicious Kitchen } \\
\text { karena daya tahan } \\
\text { makanannya yang } \\
\text { terjamin }\end{array}$ & 4,40 & $\begin{array}{l}\text { Sangat } \\
\text { Setuju }\end{array}$ \\
\hline \multicolumn{2}{|l}{ Mean Total } & 4,38 & $\begin{array}{l}\text { Sangat } \\
\text { Setuju }\end{array}$ \\
\hline
\end{tabular}

Sumber: data diolah (2020)

Hasil deskriptif terhadap kualitas produk memiliki rata-rata 4,38. Angka ini menunjukan bahwa konsumen yang melakukan pembelian makanan di Deilicious Kitchen merasa sangat setuju bahwa kualitas makanan dari Deilicious Kitchen termasuk faktor pendorong atau perangsang konsumen ketika melakukan pembelian di Deilicious Kitchen. Dari dua item pernyataan terkait variabel kualitas, dapat dilihat bahwa mean dari bahan makanan yang bersih dan segar lebih tinggi dibandingkan dengan daya tahan makanannya. Hal ini dapat diartikan bahwa konsumen lebih memprioritaskan kondisi bahan dibandingkan daya tahan makanan.

Ketika melakukan transaksi belanja baik offline maupun online, konsumen akan memperhatikan kualitas dari barang atau jasa yang ditawarkan. Akan tetapi, ketika melakukan kegiatan belanja online, seringkali banyak konsumen yang merasa ragu untuk melakukan pembelian karena mereka belum tentu bisa melihat langsung barang yang akan mereka beli mulai dari bahan yang digunakan, proses pembuatan, hingga ketika barang jadi. Dalam hal ini, testimoni atau review dari konsumen sebelumnya memiliki peranan yang penting untuk mendorong dan juga meransang konsumen untuk melakukan pembelian. Bisnis juga harus berusaha meyakinkan konsumen tentang kualitas barangnya, misalnya dengan mengunggah video proses pembuatan atau mencantumkan kandungan dan komponen dari produk yang dijual.

\section{Analisis Deskriptif Terhadap Ukuran}

Tabel 4. Penilaian Ukuran

\begin{tabular}{|l|l|l|l|}
\hline No & Item Pernyataan & Mean & Kriteria \\
\hline 1 & Saya membeli & 2,84 & Cukup \\
& $\begin{array}{l}\text { makanan di } \\
\text { Deilicious Kitchen } \\
\text { karena ukuran yang } \\
\text { ditawarkan }\end{array}$ & & Setuju \\
\hline
\end{tabular}

Sumber: data diolah (2020)

Hasil deskriptif terhadap ukuran produk memiliki rata-rata 2,84. Angka ini menunjukan bahwa konsumen yang melakukan pembelian makanan di Deilicious Kitchen merasa cukup setuju bahwa ukuran atau porsi makanan dari 
Deilicious Kitchen termasuk faktor pendorong atau perangsang konsumen ketika melakukan pembelian di Deilicious Kitchen.

Keputusan konsumen melakukan pembelian makanan berdasarkan ukuran atau porsi bisa disebabkan oleh beberapa hal. Ada konsumen yang tidak terlalu suka dengan porsi yang terlalu besar karena mempertimbangkan kalori yang terkandung di dalamnya. Namun ada juga konsumen yang lebih menyukai porsi besar karena porsi besar dianggap lebih mengenyangkan dan lebih hemat. Sebuah bisnis harus bisa menciptakan ukuran yang ideal atau bisa juga menambahkan variasi ukuran agar pasar yang terjangkau semakin luas.

\section{Analisis Deskriptif Terhadap Variasi Menu}

Tabel 5. Penilaian Variasi Menu

\begin{tabular}{|c|c|c|c|}
\hline No & Item Pernyataan & Mean & Kriteria \\
\hline 1 & $\begin{array}{lr}\text { Saya } & \text { membeli } \\
\text { makanan } & \text { di } \\
\text { Deilicious } & \text { Kitchen } \\
\text { karena } & \text { pilihan } \\
\text { menunya } & \text { yang } \\
\text { banyak. } & \end{array}$ & 4,43 & $\begin{array}{l}\text { Sangat } \\
\text { Setuju }\end{array}$ \\
\hline
\end{tabular}

Sumber: data diolah (2020)

Hasil deskriptif terhadap variasi menu memiliki rata-rata 4,43. Angka ini menunjukan bahwa konsumen yang melakukan pembelian makanan di Deilicious Kitchen merasa sangat setuju bahwa variasi menu yang ditawarkan oleh Deilicious Kitchen termasuk faktor pendorong atau perangsang untuk konsumen melakukan pembelian di Deilicious Kitchen.

Konsumen akan merasa puas ketika sebuah perusahaan berhasil memenuhi kebutuhannya. Dengan adanya variasi dari menu yang ditawarkan, bisnis dapat memenuhi kebutuhan konsumen yang beraneka ragam. Semakin banyak atau lengkap variasi produk, maka konsumen akan semakin tertarik dan merasa penasaran sehingga tidak bosan untuk melakukan pembelian. Maka dari itu, sebuah bisnis harus membuat keputusan yang tepat terkait dengan variasi menu yang mereka jual.

\section{Analisis Deskriptif Terhadap Harga}

Tabel 6. Penilaian Harga

\begin{tabular}{|l|lr|c|c|}
\hline No & \multicolumn{2}{|l|}{ Item Pernyataan } & Mean & Kriteria \\
\hline 1 & Saya & membeli & 4,07 & Setuju \\
& makanan ri & & \\
& Deilicious $\quad$ Kitchen & & \\
& karena harganya & & \\
& \multicolumn{2}{|l|}{ yang terjangkau } & & \\
\hline
\end{tabular}

Sumber: data diolah (2020)

Hasil deskriptif terhadap harga memiliki rata-rata 4,07. Angka ini menunjukan bahwa konsumen yang melakukan pembelian makanan di Deilicious Kitchen merasa setuju bahwa harga yang ditawarkan oleh Deilicious Kitchen termasuk faktor pendorong atau perangsang untuk konsumen melakukan pembelian di Deilicious Kitchen. Pernyataan ini juga didukung oleh hasil wawancara bersama pemilik Deilicious Kitchen yang menyatakan banyak konsumen mengatakan bahwa harga yang ditawarkan oleh Deilicious Kitchen termasuk murah dan membuat mereka puas.

Menurut Kotler dan Keller dalam (Mulyadi, 2017), ada lima tujuan utama yang dapat diharapkan oleh sebuah perusahaan melalui penetapan harga. Lima tujuan ini adalah bertahan hidup (survival), laba saat ini yang maksimal (maximum current profit), pangsa pasar yang maksimum (maximum market share), pemerahan pasar yang maksimal (maximum market skimming), dan yang terakhir adalah pemimpin dalam kualitas (product quality leadership).

Harga menjadi salah satu faktor yang mendorong konsumen dalam melakukan pembelian suatu produk. Oleh karena itu, 
sebuah bisnis harus menentukan harga dengan hati-hati. Perusahaan atau bisnis harus bisa menetapkan harga yang cocok dengan nilai yang diberikan dan dipahami oleh seorang konsumen, Jika harga yang ditawarkan lebih tinggi dibandingkan dengan nilai yang diterima, maka perusahaan akan kehilangan kesempatan untuk mendapatkan laba. Jika harga yang ditawarkan terlalu rendah daripada nilai yang diterima, maka perusahaan tidak akan berhasil memiliki kesempatan untuk memperoleh laba (Molan, 2005).

\section{Analisis Deskriptif Terhadap Penampilan}

Tabel 7. Penilaian Penampilan

\begin{tabular}{|l|l|c|c|}
\hline No & $\begin{array}{l}\text { Item } \\
\text { Pernyataan }\end{array}$ & Mean & Kriteria \\
\hline 1. & $\begin{array}{l}\text { Saya membeli } \\
\text { makanan di } \\
\text { Deilicious } \\
\text { Kitchen } \text { karena } \\
\text { kemasan yang } \\
\text { bagus dan } \\
\text { menarik }\end{array}$ & 3,82 & Setuju \\
\hline 2. & $\begin{array}{l}\text { Saya membeli } \\
\text { makanan di } \\
\text { Deilicious } \\
\text { Kitchen } \text { karena } \\
\text { penataan } \\
\text { makanannya } \\
\text { yang rapi dan } \\
\text { cantik }\end{array}$ & 3,74 & Setuju \\
\hline
\end{tabular}

Sumber: data diolah (2020)

Hasil deskriptif terhadap penampilan memiliki rata-rata 3,78. Angka ini menunjukan bahwa konsumen yang melakukan pembelian makanan di Deilicious Kitchen merasa setuju bahwa penampilan produk di Deilicious Kitchen termasuk faktor pendorong atau perangsang untuk konsumen melakukan pembelian di Deilicious Kitchen. Dari dua item pernyataan terkait variabel penampilan, dapat dilihat bahwa mean dari penampilan kemasan lebih tinggi daripada penataan makanan. Hal ini dapat diartikan bahwa konsumen lebih memprioritaskan kemasan makanan dibandingkan penataan makanan di dalamnya. Pernyataan ini didukung juga dengan hasil wawancara bersama pemilik yang menyatakan bahwa banyak konsumen yang melakukan pembelian karena tampilan makanan Deilicious Kitchen terlihat menarik ketika diunggah di media sosial.

Penampilan produk menjadi salah satu hal yang penting dalam memasarkan produk karena akan menentukan pandangan atau penilaian konsumen terhadap produk tersebut. Penampilan ini dapat dilihat dari bentuk dan desain kemasan produknya serta bagaimana produk tersebut ditata di dalam kemasan. Kemasan produk akan menyampaikan produk apa yang ditawarkan oleh sebuah bisnis. Saat ini bisnis berlombalomba membuat kemasan produk yang bagus dan menarik agar bisa memberikan kesan yang baik kepada konsumen dan mendorong mereka untuk melakukan pembelian. Tidak hanya desain, bahan kemasan produk kini juga menjadi perhatian dari konsumen. Banyak konsumen yang lebih memilih produk dengan kemasan ecofriendly walaupun desain kemasannya sangat sederhana. Secara tidak langsung, kemasan yang bagus dan menarik akan membantu bisnis mendapatkan kepercayaan dari konsumen dan membentuk citra baik.

Selain itu, visual makanan atau dalam hal ini adalah cara penataan makanan juga menjadi salah satu hal yang penting. Penataan makanan yang rapi dan cantik dapat memengaruhi rasa lapar seseorang dan mendorong mereka untuk menyantap hidangan tersebut. Tujuan dari penataan makanan sendiri adalah untuk menggugah selera calon konsumen dan menciptakan kesetiaan. Penataan komposisi makanan di dalam kemasan juga tidak bisa asal karena ada ketentuan kalori di tiap-tiap makanan. 
Penataan makanan yang baik akan membantu bisnis untuk mengetahui seperti apa komposisi makanan yang ideal.

\section{Analisis Deskriptif Terhadap Rasa Senang}

Tabel 8. Penilaian Rasa Senang

\begin{tabular}{|c|c|c|c|}
\hline No & Item Pernyataan & Mean & Kriteria \\
\hline \multirow[t]{6}{*}{1} & Saya membeli & \multirow[t]{6}{*}{2,13} & \multirow{6}{*}{$\begin{array}{l}\text { Tidak } \\
\text { Setuju }\end{array}$} \\
\hline & makanan & & \\
\hline & Deilicious & & \\
\hline & karena rasa senang & & \\
\hline & yang akan saya & & \\
\hline & dapatkan & & \\
\hline
\end{tabular}

Sumber: data diolah (2020)

Hasil deskriptif terhadap Rasa Senang memiliki rata-rata 2,13. Angka ini menunjukan bahwa konsumen yang melakukan pembelian makanan di Deilicious Kitchen merasa tidak setuju bahwa rasa senang yang akan didapatkan termasuk faktor pendorong atau perangsang untuk konsumen melakukan pembelian di Deilicious Kitchen.

Rasa senang yang didapatkan konsumen bisa disebabkan oleh berbagai alasan, seperti rasa senang karena membeli makanan yang disukai atau senang karena kebutuhan akan rasa laparnya terpenuhi.

\section{Formulasi Strategi Produk dan Harga yang diusulkan untuk Deilicious Kitchen}

Berdasarkan hasil analisis deskriptif pada beberapa motif pembelian baik motif rasional maupun motif emosional, ditemukan ada beberapa motif yang menjadi pendorong atau perangsang paling dominan ketika konsumen melakukan pembelian di Deilicious Kitchen. Motif tersebut adalah variasi menu, kualitas, harga, dan penampilan. Hal tersebut kemudian menjadi peluang yang perlu dikembangkan Deilicious Kitchen agar dapat tetap bertahan di tengah-tengah persaingan. Untuk membahas strategi pemasaran yang tepat terkait produk dan harga, maka dilakukan diskusi bersama beberapa praktisi yang sesuai dengan bidangnya.

Motif pembelian dengan nilai tertinggi adalah variasi menu yang termasuk ke dalam motif pembelian rasional. Berdasarkan hasil diskusi bersama praktisi yang sesuai dengan bidangnya, maka strategi yang cocok untuk diterapkan adalah pengembangan dari menu yang sudah ada dan juga penambahan menu baru. Untuk menu nasi bakar yang menjadi salah satu best seller dari Deilicious Kitchen, pemilik disarankan untuk menambah varian nasi bakar. Saat ini hanya ada satu varian nasi bakar dari Deilicious Kitchen dan isi dari nasi bakar tersebut adalah sayuran, ayam, dan ikan. Praktisi menyarankan untuk memisahkan bahan-bahan tersebut sehingga varian nasi bakar akan lebih banyak, yaitu nasi bakar ayam, nasi bakar ikan, dan nasi bakar sayur.

Hal ini juga mempertimbangkan ada beberapa orang yang tidak suka ikan, tidak suka ayam, atau tidak suka sayur. Pemisahan nasi bakar menjadi tiga varian ini juga diharapkan dapat menekan biaya produksi dan dapat menjangkau pasar yang lebih luas lagi. Lalu praktisi juga menyarankan adanya penambahan menu makanan laut (seafood) karena saat ini Deilicious Kitchen belum menjualnya padahal penikmat makanan laut cukup banyak. Ada beberapa saran menu yang diberikan seperti kerang saus padang, kerang cabai hijau, ikan bakar, ikan asam manis, cumi goreng tepung, dan udang goreng mentega. Saran yang diberikan oleh praktisi ini sudah disesuaikan dengan kemampuan Deilicious Kitchen untuk menyediakan hidangan tersebut dan dengan mempertimbangkan harga bahan-bahan tersebut di pasar. Untuk menu-menu lain 
seperti cemilan disarankan untuk tetap dipertahankan.

Lalu motif selanjutnya adalah Kualitas yang termasuk motif pembelian rasional. Untuk kualitas, praktisi menyarankan untuk membeli bahan-bahan yang segar agar makanan yang di jual juga tahan lama. Hal ini juga mempertimbangkan hasil dari kuesioner bahwa konsumen memperhatikan bahan-bahan yang digunakan. Deilicious Kitchen juga perlu mempertahankan konsistensi dari kualitas produknya agar konsumen merasa puas dan bisa mendorong mereka untuk melakukan pembelian berulang. Deilicious Kitchen disarankan untuk membuat konten-konten terkait kegiatan produksi makanan agar konsumen dapat lebih percaya dengan kualitas makanan yang diproduksi.

Item pendorong yang ketiga adalah harga produk yang termasuk motif pembelian rasional. Dari hasil diskusi bersama praktisi, maka strategi yang cocok adalah melakukan promo atau diskon. Promo ini bisa dilakukan di saat-saat tertentu seperti saat hari-hari penting (hari ibu, hari kemerdekaan, hari kartini) atau ketika ada promo di platform-platform online (promo 11.11, big sale). Promo yang dilakukan dapat berupa potongan harga, buy 1 get 1 , atau potongan ongkos kirim. Untuk harga dari makanan sendiri sudah cukup sesuai dengan apa yang ditawarkan sehingga diusahakan untuk dipertahankan.

Lalu motif terakhir yang juga memiliki peluang untuk dikembangkan adalah penampilan yang termasuk motif pembelian emosional. Berdasarkan hasil diskusi bersama praktisi yang sesuai dengan bidangnya, maka strategi yang cocok adalah mengganti kemasan Deilicious Kitchen. Setelah melakukan wawancara bersama pemilik, ditemukan bahwa kemasan menjadi salah satu hal yang sensitif untuk para konsumen. Pemilik sering menerima saransaran terkait dengan kemasan makanan. Ada beberapa konsumen yang ingin kemasan produknya ramah lingkungan. Saat ini, kemasan yang digunakan oleh Deilicious Kitchen merupakan plastik dengan stiker logo yang ditempel di tengah-tengah penutup kemasan.

Untuk mengatasi hal tersebut, praktisi menyarankan untuk mengganti kemasan Deilicious Kitchen menjadi bahan kertas yang terbuat dari food grade paper agar tahan panas. Kemasan ini digunakan untuk membungkus makanan berat dan telah digunakan di beberapa restoran besar. Bahan kemasan food grade paper disarankan karena lebih ramah lingkungan dibandingkan bahan plastik. Untuk desain logo disarankan agar mengganti warna logo menjadi warna yang lebih gelap dan netral seperti hitam, putih, atau coklat mengingat target pasar dari Deilicious Kitchen juga mencakup segmen umur dewasa. Logo ini kemudian akan di cetak menjadi stiker dengan ukuran yang lebih besar dibandingkan sebelumnya agar dapat digunakan untuk menyegel kemasan dan akan membuat orang-orang lebih sadar dengan nama dari Deilicious Kitchen. Untuk menu nasi kotak, praktisi menyarankan penggunaan 'besek' karena akan menjadi nilai tambah dan menjadi pembeda dengan para pesaingnya. Penggunaan besek juga sesuai dengan keinginan konsumen untuk membeli produk dengan kemasan ramah lingkungan. Untuk pembelian seluruh kemasan sebaiknya dilakukan secara bersamaan agar menghemat biaya kemasan.

Untuk penampilan yang terkait dengan penataan makanan, praktisi menyarankan agar makanan yang disajikan jangan terlalu berlebihan. Makanan sebaiknya disajikan dengan takaran yang pas. Lalu agar lebih menarik perhatian, makanan bisa dibuat 
lebih berwarna atau diberikan hiasan-hiasan seperti sayuran. Untuk nasi kotak yang menggunakan besek, praktisi menyarankan untuk menggunakan daun pisang sebagai alas dan pembatas lauk-lauk didalamnya. Hal ini dilakukan agar lauk pauk tidak berceceran dan terlihat lebih menarik.

Semua strategi yang disarankan oleh para praktisi sudah menyesuaikan dengan kondisi dan kemampuan dari Deilicious Kitchen agar lebih mudah untuk diterapkan.

\section{SIMPULAN DAN SARAN}

\section{Simpulan}

Penelitian ini bertujuan untuk mengetahui motivasi konsumen dalam melakukan pembelian di Deilicious Kitchen yang hasilnya akan digunakan untuk memperbaiki strategi produk dan harga. Dari hasil penelitian ini, maka dapat ditarik simpulan bahwa dengan menggunakan teknik analisis deskriptif pada data yang diperoleh dari hasil penyebaran kuesioner kepada konsumen Deilicious Kitchen, peneliti menemukan terdapat empat dominant buying motives yang mendorong atau meransang konsumen untuk melakukan pembelian makanan di Deilicious Kitchen.

Berdasarkan analisis deskriptif, variabel variasi menu memiliki nilai ratarata paling tinggi diantara variabel yang lain dengan angka 4,43. Maka dari itu, variabel variasi menu menjadi hal yang paling mendorong konsumen melakukan pembelian dan perlu menjadi perhatian dari Deilicious Kitchen. Lalu variabel selanjutnya adalah kualitas produk dengan nilai rata-rata 4,38 , di posisi ketiga adalah harga produk dengan nilai rata-rata 4,07, dan variabel terakhir adalah penampilan dengan nilai rata-rata 3,78.

Strategi produk dan harga yang diusulkan untuk Deilicious Kitchen menyesuaikan dengan empat nilai dominan tersebut. Hal yang dapat dilakukan oleh Deilicious Kitchen terkait dengan strategi produk dan harganya adalah melakukan pengembangan terhadap variasi menu, menjaga konsistensi kualitas produk, melakukan promo serta potongan harga produk, dan melakukan perbaikan pada penampilan produknya baik dari kemasan makanan hingga penataan makanan dalam kemasan.

\section{Saran}

Untuk penelitian yang selanjutnya diharapkan peneliti lain dapat mengembangkan lagi indikator yang digunakan untuk mengukur motif rasional dan motif emosional dalam melakukan pembelian. Hal ini disarankan agar hasil yang didapatkan akan lebih akurat dan relevan dengan kondisi di lapangan. Peneliti juga dapat menggunakan variabel lain yang memengaruhi keputusan pembelian konsumen.

Berdasarkan dari hasil kesimpulan yang didapatkan, maka saran yang dapat diusulkan kepada Deilicious Kitchen terkait strategi produk dan harga adalah memprioritaskan empat dominant buying motives untuk diperbaiki dan dikembangkan lagi. Analisis terkait motivasi konsumen ini perlu dilakukan secara berkala, bisa dengan melalui survei konsumen agar Deilicious Kitchen dapat terus berkembang dan bertahan di tengah-tengah persaingan.

\section{DAFTAR PUSTAKA}

Kompas.com. (2020). Pandemi Covid-19 Pengaruhi Pola Belanja, Apa yang Jadi Tren? https://money.kompas.com/read/2020/0 7/10/152826026/pandemi-covid-19pengaruhi-pola-belanja-apa-yang-jaditren?page $=$ all

Kotler, P. (2002). Manajemen Pemasaran. Prehallindo. 
Kotler, P., \& Amstrong, G. (2001). PrinsipPrinsip Pemasaran (12th ed.). Erlangga.

Manning, G. L., Ahearne, M., \& Reece, B. L. (2012). Selling Today: Partnering to Create Value. Pearson Prentice Hall.

Molan, B. (2005). Manajemen Pemasaran. Indeks Kelompok Media.

Mothersbaugh, D. L., \& Hawkins, D. I. (2016). Consumer Behavior Build Marketing Strategy 13th edition. In McGraw-Hill Education (Vol. 13). McGraw-Hill Education. https://doi.org/10.2307/1251656

Mulyadi, H. (2017). Analisis Penetapan Harga PD. Jasa Saudara Textile. Jurnal Manajemen Pemasaran, 12(2), 101112.

Naashir, M., Istiatin, \& Hartono, S. (2016). Pengaruh Motivasi, Persepsi, dan Sikap Konsumen Terhadap Keputusan Pembelian Sepeda Motor Pada Dealer Honda Astra Motor Palur. Jurnal Studi Manajemen Dan Organisasi.

Priyono. (2008). Metode Penelitian Kuantitatif. Zifatama Publisher.

Schiffman, L. G., \& Wisenblit, J. L. (2015).
Consumer Behavior, Eleventh Edition. In Consumer Behavior (Issue 6).

Setiadi, N. J. (2003). Perilaku Konsumen: Konsep dan Implikasi untuk Strategi dan Penelitian Pemasaran. Kencana Prenada Media.

Setiadi, N. J. (2010). Perilaku Konsumen. Kencana Prenada Media.

Setiawan, \& Harahab, N. (2013). Analisis Motivasi Dan Kepuasan Konsumen Terhadap Produk Olahan Seafood. ECSOFiM, 1(1), 109-116.

Sugiyono. (2013). Metode Penelitian kuantitatif kualitatif dan $R \& D$. Alfabeta.

Yusa, V. De. (2015). Pengaruh Motif Rasional dan Motif Emosional Terhadap Keputusan Pembelian Ponsel Blackberry di Bandar Lampung. Jurnal Ekonomi Dan Manajemen, 9(2), 97111. 